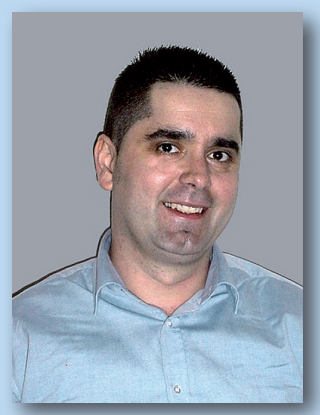

doc. dr. sci. Almir Alihodžić

Univerzitet u Zenici, Ekonomski fakultet Zenica almir.alihodzic@ef.unze.ba

\section{PRORAČUN TRAJANJA}

ZA ODREĐENE

OBVEZNICE NA

FINANSIJSKOM TRŽIŠTU U BIH

\title{
Rezime
}

Trajanje je glavna mjera cenovne osetljivosti koja se koristi na tržištu obveznica. Pokazuje koliko se menja cena obveznice pod uticajem promene tržišnih kamatnih stopa. Između cena i prinosa obveznica postoji inverzna veza preko kamatnih stopa. S porastom i padom kamatnih stopa vlasnici obveznica ostvaruju kapitalne dobitke i gubitke. Osnovni cilj ovog rada je da se utvrdi osetljivost pojedinih obveznica na finansijskom tržištu u BiH s promenom roka dospeća, kao i značaj obveznica kao alternativnog vida finansiranja.

Ključne reči: duracija, modifikovano trajanje, konveksnost, prinos do dospeća JEL: G1, G11, G12 


\section{CALCULATION OF CERTAIN BONDS DURATION ON THE FINANCIAL MARKET OF BOSNIA AND HERZEGOVINA}

doc. dr. sci. Almir Alihodžić University of Zenica Faculty of Economics Zenica almir.alihodzic@ef.unze.ba

\section{Summary}

Duration is the main measure of price sensitivity which is used on the bond market. It indicates how much the bond price would change under the impact of change in the market interest rates. There is an inverse link between the bond price and yield through the interest rates. With the rise and fall of interest rates bond holder makes capital gain or loss. The main objective of this work is to determine sensitivity of certain bonds on the financial market of Bosnia and Herzegovina $(\mathrm{BiH})$ to the change in maturity term, and the importance of bonds as an alternative form of financing.

Key words: duration, modified duration, convexity, yield to maturity JEL: G1, G11, G12 


\section{Uvod}

Pasivni menadžeri pretpostavljaju da su cene obveznica realne, te je njihov cilj samo da kontrolišu rizik svojih portfolija s fiksnim prihodom. Generalno govoreći ovaj rizik se može sagledati na dva načina $u$ zavisnosti od okolnosti u kojima se nalazi investitor. $\mathrm{Na}$ primer, neke institucije kao što su banke, teže da zaštite tekuću neto vrednost ili neto tržišnu vrednost portfolija od promena kamatnih stopa. Drugi investitori kao što su penzioni fondovi mogu imati investicioni cilj koji treba ostvariti posle određenog broja godina. Za razliku od pasivnih, aktivne strategije investiranja imaju za cilj ostvarivanje prinosa koji su viši nego srazmjerni preuzetom riziku. Na primer kod portfolija obveznica ovaj stil upravljanja može imati dva oblika. Aktivni menadžeri mogu da koriste prognozirane kamatne stope u predviđanju opštih kretanja na tržištu obveznica, odnosno mogu primeniti neki drugi vid unutrašnje analize da bi odredili određene sektore tržišta. Dakle, ono što je zajedničko svim finansijskim institucijama je kamatni rizik. Neto vrednost preduzeća i njihova sposobnost da izmiruju buduće obaveze menja se s promenama kamatnih stopa. Finansijske institucije uz odgovarajuću strukturu dospeća svojih portfolija, mogu ublažiti kamatni rizik. Imunizacija i druge strategije pomažu investitorima da zaštite neto vrednost svojih portfolija od promena kamatnih stopa. Predmet istraživanja u ovom radu je proračun trajanja kao mere kreditnog rizika za određenu skupinu obveznica na finansijskom tržištu u BiH. Rad je struktuiran iz tri dela. U prvom delu se opisuju teorijske osnove obveznica, tj. način utvrđivanja cena, prinosa i osetljivosti obveznica na promenu kamatnih stopa. U drugom delu se opisuje sama mera trajanja, modifikovanog trajanja i konveksnosti i njihova zavisnost od promene kamatne stope. U trećem delu se analizira trenutni stepen razvoja tržišta obveznica u $\mathrm{BiH}$ i proračunava se mera trajanja za određenu skupinu obveznica. Na samom kraju se navode zaključci kao rezultati provedenog istraživanja.

\section{Utvrđivanje i promenljivost cena obveznica}

U sekundarnom prometu cena obveznica po pravilu nije jednaka njenoj nominalnoj vrednosti. Dakle, cena obveznice je približno jednaka sadašnjoj vrednosti očekivanog cash flow - a finansijskog instrumenta. Kako bi se odredila cena obveznice potrebno je znati: procenu očekivanog cash flow - $a$ i procenu očekivanog prinosa. Cash flow se sastoji iz: periodičnih godišnjih isplata kupona do dana dospeća i nominalne vrednosti na dan dospeća. Stopa očekivanog prinosa utvrđuje se na osnovu prinosa koji ostvaruju obveznice sličnog rizika na tržištu. Ako se kamata plaća samo jednom godišnje algebarska formulacija cene obveznice je:

$P=\frac{C}{(1+r)}+\frac{C}{(1+r)^{2}}+\frac{C}{(1+r)^{3}}+\cdots+\frac{C}{(1+r)^{n}}+\frac{M}{(1+r)^{n}}(1)$

Odnosno:

$P=\sum_{t=1}^{n} \frac{C}{(1+r)^{t}}+\frac{M}{(1+r)^{n}}$

Gde su: $P$ - unutrašnja vrijednost obveznice; $C$ - godišnja vrednost kupona; $M$ - nominalna vrednost obveznice, $n$ - godina do dospeća i $r$ - zahtevani prinos ili preovladajuća tržišna kamatna stopa na plasman istog nivoa rizika.

Kada se kupon isplaćuje više puta godišnje jednačina (2) se modifikuje i poprima sledeći oblik:

$P=\frac{\frac{C}{m}}{\left(1+\frac{r}{m}\right)^{1}}+\frac{\frac{C}{m}}{\left(1+\frac{r}{m}\right)^{2}}+\cdots+\frac{\frac{C}{m}+M}{\left(1+\frac{r}{m}\right)^{m n}}$

Gde su: $n$ - broj godina i $m$ - broj isplata u toku jedne godine.

Kod obveznica bez kupona ne postoji periodičnost isplate kupona. Investitor ostvaruje prinos kao razliku između kupovne i prodajne cene, tj. između nabavne cene i nominalne vrednosti ako se ona isplaćuje o roku dospeća. Cena kod obveznice bez kupona se izražava na sledeći način: 


\section{Introduction}

Passive managers assume that bond prices are real, hence their target is only to control their fixed yield portfolio risk. Generally speaking, this risk can be assessed in two ways, depending on the circumstances that the investor is facing. For example, some institutions such as banks tend to protect portfolio current net value or net market value from the interest rate changes. Other investors, such as the pension funds, may have their investment targets that will be realized after a certain number of years. Opposite to the passive, active investment strategies have the aim to achieve yields that are higher than the proportionate risk exposure. For example, in case of bonds portfolio, this management style may have two forms. Active managers may apply prognosticated interest rates in their forecasts of the general bond market movements, or they may apply some other form of internal analysis in order to determine certain market sectors. Therefore what is common for all the financial institutions is the interest risk. Net company value and their ability to service future liabilities will change with the change in the interest rates. Financial institutions, with the appropriate maturity structure of their portfolios, may mitigate interest risk. Immunization and other strategies are helping investors to protect net value of their portfolios from the change in the interest rates. The subject of research in this work is the calculation of duration as the measure of credit risk for a certain set of bonds on the financial market of $\mathrm{BiH}$. The paper is structured in three parts. In part one, description is given of the bond theoretical basis, i.e. the manner of setting price, yield and bond sensitivity. In part two, there is a description of the duration measure itself, modified duration and convexity and their dependence on the interest rate changes. In part three, the current degree of the bond market development in $\mathrm{BiH}$ is analyzed, and the duration measure is calculated for a certain set of bonds. Finally, conclusions are made as a result of the conducted research.

\section{Determination and bond price volatility}

In the secondary trading the bond price, as a rule, is not equal to its nominal value. Hence the bond price is approximately equal to the present value of the expected cash flow of the financial instrument. In order to determine the bond price it is necessary to know the following: estimation of the expected cash flow and the assessment of the expected yield. Cash flow consists: of the periodic annual coupon payment up to the maturity date and the nominal value on the maturity date. The expected yield rate is determined on the basis of the yield achieved on the similar risk exposed bonds on the market. If the interest is paid only once a year, the algebra price formulation of a bond would be as follows:

$P=\frac{C}{(1+r)}+\frac{C}{(1+r)^{2}}+\frac{C}{(1+r)^{3}}+\cdots+\frac{C}{(1+r)^{n}}+\frac{M}{(1+r)^{n}}(1)$

Or:

$P=\sum_{t=1}^{n} \frac{C}{(1+r)^{t}}+\frac{M}{(1+r)^{n}}$

Where: $P$ is the internal bond value; $C$ is the annual coupon value; $M$ is the nominal bond value, $n$ is the number of years to maturity, and $r$ is the required yield or the prevailing market interest rate on the placement of the same level of risk.

When the coupon is paid several times a year, the equation (3) is modified and acquires the following shape:

$P=\frac{\frac{C}{m}}{\left(1+\frac{r}{m}\right)^{1}}+\frac{\frac{C}{m}}{\left(1+\frac{r}{m}\right)^{2}}+\cdots+\frac{\frac{C}{m}+M}{\left(1+\frac{r}{m}\right)^{m n}}$

Where $\mathrm{n}$ is the number of years, and $\mathrm{m}$ is the number of payments made during one year.

In case of zero coupon bonds, there is no periodic payment of coupons. The investor is receiving yield as a difference between the purchase and the sale price, i.e. between the supply and the nominal value, if it is to be paid on maturity. The price of a zero coupon bond is expressed in the following manner: 
$P=\frac{M}{(1+r)^{n}}$

Kao što je i rečeno promena cene obveznice usled promene tržišnih kamatnih stopa koje predstavljaju nivo zahtevanog prinosa. Dakle, ako je kuponska kamatna stopa obveznice veća od zahtevanog prinosa, cena obveznice je veća od nominalne vrednosti i na primarnom tržištu se prodaje uz premiju. Obrnuto, ako je nominalna kamatna stopa manja od tržišne vlasnici datih obveznica će ostvariti prinos manji od tržišnog, gde će se takve obveznice na sekundarnom tržištu prodavati uz diskont. Cena obveznice se izražava kao procent $u$ odnosu na nominalnu vrednost. Ova procedura je poznata pod nazivom kotacija, što ilustruje sledeća tabela.

Tabela 1: Tradicionalno i današnje izražavanje cene obveznice

\begin{tabular}{|l|r|r|r|}
\hline $\begin{array}{c}\text { Kotacija } \\
\text { (tradicionalni } \\
\text { način) }\end{array}$ & $\begin{array}{c}\text { Kotacija u } \\
\text { decimalnom } \\
\text { sistemu } \\
{[\mathbf{l = ( 1 ) / 1 0 0 ]}}\end{array}$ & $\begin{array}{c}\text { Nominalna } \\
\text { vrednost } \\
\text { obveznice }\end{array}$ & $\begin{array}{c}\text { Cena } \\
\text { izražena u } \\
\text { n.j. }\end{array}$ \\
\hline 97 & 2 & 3 & $4(2 \times 3)$ \\
\hline $85^{1 / 2}$ & 0,9700000 & $10.000,00$ & $9.700,00$ \\
\hline $90^{1 / 4}$ & 0,8550000 & $100.000,00$ & $85.500,00$ \\
\hline $80^{1 / 8}$ & 0,8012500 & $10.000,00$ & $8.012,50$ \\
\hline $76^{5 / 32}$ & 0,7615625 & $1.000 .000,00$ & $761.562,50$ \\
\hline $86^{11 / 64}$ & 0,8617188 & $100.000,00$ & $86.171,88$ \\
\hline 100 & 1,0000000 & $50.000,00$ & $50.000,00$ \\
\hline 109 & 1,0900000 & $1.000,00$ & $1.090,00$ \\
\hline $103^{3 / 4}$ & 1,0375000 & $100.000,00$ & $103.750,00$ \\
\hline $05^{3 / 8}$ & 1,0537500 & $25.000,00$ & $26.343,75$ \\
\hline $03^{19 / 32}$ & 1,0359375 & $1.000 .000,00$ & $1.035 .937,50$ \\
\hline
\end{tabular}

Izvor: Šoškić, D., Živković, B. str. 267.

Između cijena i prinosa obveznica postoji inverzna veza, tako da se kamatne stope mogu u značajnoj mjeri mijenjati. Kako kamatne stope rastu i padaju vlasnici obveznica ostvaruju različite kapitalne gubitke i dobitke. Naime, zbog datih kretanja ulaganja s fiksnim dohotkom su rizična. Trajanje je osnovni koncept $\mathrm{u}$ upravljanju portfolijom s fiksnim prinosom iz tri jednostavna razloga. Kao prvo predstavlja jednostavnu meru efektivnog prosečnog dospeća portfolija. Kao drugo, to je osnovni alat za imunizaciju portfolija od kamatnog rizika. I treće trajanje predstavlja meru osetljivosti obvezničkog portfolija na promene kamatnih stopa. Dugoročne obveznice su osetljivije na promene kamatnih stopa od kratkoročnih. U nastavku teksta biće nešto više reči o konceptu trajanja i imunizacije. Savremena finansijska teorija je posebnu pažnju posvetila pitanjima određivanja vrednosti obveznica. Najpoznatije teoreme koje tretiraju vrednost obveznica odnose se na sledeće:

- Kada raste kamatna stopa dolazi do pada obveznica i obrnuto, odnosno, kretanje kamatne stope i cena obveznica je inverzno.

- Ukoliko se prinos do dospeća ne menja u toku životnog veka obveznice, onda će s protekom vremena dolaziti do smanjivanja veličine njenog diskonta ili premije.

- $\quad$ Ukoliko se prinos do dospeća u toku životnog veka obveznice ne menja, tada će se diskont ili premija smanjivati po rastućoj stopi kako životni vek obveznice postaje kraći.

- Smanjivanje kamatnih stopa će brže povećavati cenu obveznica, nego što će povećanje kamatnih stopa smanjivati cenu.

- Procent promena cena obveznica u odnosu na promene kamatne stope biće manji ukoliko je stopa kupona veća, odnosno obveznice s većim kuponima imaju za implikaciju manju procentualnu promenu cena usled promena kamatnih stopa.

Teoreme o kretanju cena obveznica su posebno značajne pri određivanju vrednosti obveznica, kao i za upravljanje njihovim portfoliom. Naime, analiza vrednosti obveznica i kretanja njihovih cena je jednako važna za mnoge učesnike na finansijskim tržištima, jer poznavanje ove problematike pomaže $u$ adekvatnom upravljanju portfoliom obveznica, finansijskom planiranju itd. 


$$
P=\frac{M}{(1+r)^{n}}
$$

As already mentioned, the change of the bond price is due to the change in the market interest rates which represent the level of yield required. Hence, if the bond coupon interest rate is higher that the required yield, the bond price is higher than the nominal value and on the primary market is sold with the premium. Conversely, if the nominal interest rate is lower than the market rate, holders of given bonds will acquire yield lower than the market one, where such bonds will be sold on the secondary market with a discount. Bond price is expressed as a percentage in respect to the nominal value. This procedure is known as quotation, which is illustrated in the following table.

simple reasons. Firstly, it is a simple measure of effective average portfolio maturity. Secondly, it serves as the basic tool for the interest rate risk portfolio immunization. And thirdly, duration is the measure of sensitivity of the bond portfolio to the interest rate changes. Long-term bonds are more sensitive to the interest rate changes than the short-term ones. Further in this paper we shall examine in more detail the concept of duration and immunization. Contemporary financial theory focused its special attention to the matters of determining the value of bonds. The best known theorems treating the bond value pertain to the following:

- When the interest rate is on the raise, the bonds fall, and vice versa, i.e. the interest rate and the bond price movements are inversed.

- If the yield to maturity is not to change during the life span of the bond, then with the elapse of time what will occur is the fall in size of its discount or premium.

- $\quad$ If the yield to maturity during the life span of the bond remains unchanged, then the discount or the premium will fall at a growing rate as the life span of the bond becomes shorter.

- $\quad$ Lowering of the interest rates will increase the bond price faster than would the growth of the interest rates lower the price.

- $\quad$ Percentage of the bond price change with the change in the interest rate will be lower if the coupon rate is higher, i.e. bonds with higher coupons have as implication lower percentage price change due to the change in the interest rates.

Theorems dealing with the bond price movement are especially important in determining the bond

There is an inverse connection between the bond price and its yield, so that the interest rates may substantially change. If the interest rates are to grow or fall, bond holders make different capital gains or losses. Namely, because of the given movements, fixed return investments are risky. Duration is the basic concept in the fixed yield portfolio management for three value, and also in their portfolio management. Namely, the bond value analysis and their price movement is equally important for many stakeholders on financial markets, as the knowledge of these matters helps achieve an adequate bonds portfolio management, financial planning, etc. 


\section{Koncept trajanja i njegovo računanje}

Pojam trajanja uglavnom se vezuje za vrijednosne papire $\mathrm{s}$ fiksnim prinosom $\mathrm{i}$ to klasične obveznice s periodičnom kuponskom isplatom kamata. Dakle, kod ovih obveznica vrijeme dospjeća predstavlja samo trenutak otplate nominalnog duga, a ne i ostale isplate kao što su godišnje ili polugodišnje kamate. Postavlja se opravdano pitanje: Šta je s prinosom koji se može ostvariti reinvestiranjem periodično isplaćenih kamata? Naime kod ovih obveznica za razliku od obveznica s nultim kuponom, odnos vremena dospeća i kamatne stope upisane u kuponima ne govori dovoljno o vrednosti obveznice, tj. o prinosu koji se može ostvariti ulaganjem u takvu obveznicu. Ovaj nedostatak se ispravlja uvođenjem termina trajanja obveznice. Izvorno termin definiše Frederick R. Macaulay u studiji objavljenoj još 1938. godine, gde u upotrebi ovaj pojam dolazi tek u sedamdesetim godinama prošlog veka. On je predložio da se trajanje računa kao ponderisani prosek rokova do svake kuponske isplate i isplate glavnice koje prima vlasnik obveznice. Ponder koji se pripisuje svakom vremenskom periodu treba da bude povezan s važnošću date isplate za vrednost obveznice. Dakle, trajanje predstavlja meru osetljivosti cena obveznica na promenu kamatnih stopa, odnosno pojašnjava koliko se cena obveznica menja u odnosu na promenu kamatnih stopa. U matematici ovakve promene izražavaju se u obliku diferencijalnih jednačina. Prvi deo jednačine (1) je cijena za standardnu kuponsku obveznicu (engl. plainvanilla). S obzirom da je cena $P$ funkcija prinosa $r$. Ako se sada diferencira jednačina za cenu/ prinos standardne kuponske obveznice dolazi se do sledećeg izraza:

$\frac{d P}{d r}=-\frac{1}{(1+r)}\left[\frac{1 C}{(1+r)}+\frac{2 C}{(1+r)^{2}}+\cdots+\frac{n C}{(1+r)^{n}}+\frac{n M}{(1+r)^{n}}\right](5)$

Odnos u zagradama iz prethodne jednačine predstavlja prosečno vreme dospeća novčanih priliva od obveznice ponderisano prema sadašnjoj vrednosti svakog pojedinačnog novčanog priliva. Dakle, cela jednačina (5) predstavlja formulu za izračunavanje približne promene u ceni koja odgovara maloj promeni prinosa. Ako sada podelimo obe strane jednačine (5) s cenom $P$ dobijamo sledeći izraz:

$\frac{d P}{d r} \cdot \frac{1}{P}=-\frac{1}{(1+r)}\left[\frac{1 C}{(1+r)}+\frac{2 C}{(1+r)^{2}}+\cdots+\frac{n C}{(1+r)^{n}}+\frac{n M}{(1+r)^{n}}\right] \frac{1}{P}$

Ako sada izraz u zagradi jednačine (6) podelimo s cenom $P$ dobijamo novi izraz koji predstavlja definiciju Macaulay-jevog trajanja, merenog u godinama:

$D=\frac{\frac{1 C}{(1+r)}+\frac{2 C}{(1+r)^{2}}+\cdots+\frac{n C}{(1+r)^{n}}+\frac{n M}{(1+r)^{n}}}{P}$

Prethodnujednačinu možemo pojednostaviti na sledeći način:

$D=\frac{\sum_{n=1}^{N} \frac{n C_{n}}{(1+r)^{n}}}{P}$

gde je: $C_{n}$ priliv sredstava od obveznice $\mathrm{u}$ vremenu $n$.

Ako se izraz za Macaulay-jevo trajanje (7) zameni u jednačini (6), pomoću koje se izračunava približna procentna promjena cene, onda dobijamo izraz za modifikovano trajanje (engl. modified duration):

$\frac{d P}{d r} \cdot \frac{1}{P}=-\frac{1}{(1+r)} D=\frac{D}{(1+r)}=-M D(9)$

odnosno:

$M D=\frac{D}{(1+r)}$

Postupak izračunavanja Macaulay-jevog trajanja moguće je skratiti, ako se jednačina za izračunavanje cena obveznica (1) izrazi na sledeći način:

$P=C\left[\frac{1-\frac{1}{(1+r)^{n}}}{r}\right]+\frac{M}{(1+r)^{n}}$

Ako prethodnu jednačinu diferenciramo pomoću prvog izvoda i podelimo sa trenutnom cenom obveznice $P$, dobićemo izraz kao alternativnu formulu za modifikovano trajanje: 


\section{Concept of duration and its calculation}

The notion of duration is mainly associated with the fixed yield securities, especially the classic bonds with periodic coupon interest payment. Therefore, in case of these bonds the maturity term is only the moment when the nominal debt is repaid, but not the other payments such as annual or semi-annual interest. There is a justified question raised here: What about the yield that can be acquired through reinvestment of periodically paid interest? Namely, in case of these bonds, contrary to the zero coupon bonds, the ratio of maturity term and the interest rate inscribed in the coupons does not show a precise picture of the bond value, i.e. of the yield that can be acquired by investing in such a bond. This drawback is rectified by introducing the bond duration term. Originally, this term was defined by Frederick R. Macaulay in his study, published back in 1938, yet the term was to be found in actual use only as late as the 1970s. He proposed that the duration be calculated as a weighted average of terms to every coupon payment and payment of principal received by the bond holder. The weight prescribed to each time period should be linked with the validity of payment made for the bond value. Hence, duration is the measure of bond price sensitivity to the change in the interest rates, i.e. it clarifies how much the bond price changes with the change in the interest rates. In mathematics, such changes are expressed in the form of differential equations. The first part of the equation (1) is the price for a standard coupon bond - plain vanilla. As the price $P$ is the function of yield (return) $r$, if the equation for the price/yield of a standard plain vanilla bond is differentiated, we come to the following expression:

$\frac{d P}{d r}=-\frac{1}{(1+r)}\left[\frac{1 C}{(1+r)}+\frac{2 C}{(1+r)^{2}}+\cdots+\frac{n C}{(1+r)^{n}}+\frac{n M}{(1+r)^{n}}\right](5)$

The ratio in the brackets from the previous equation is the average maturity term of the bond cash flows weighted at present value of each individual cash flow. Therefore the entire equation (5) stands as a formula for calculation of the approximate price change which corresponds to a small change in yield. If we are to divide now both sides of the equation (5) with the price P, we obtain the following expression:

$\frac{d P}{d r} \cdot \frac{1}{P}=-\frac{1}{(1+r)}\left[\frac{1 C}{(1+r)}+\frac{2 C}{(1+r)^{2}}+\cdots+\frac{n C}{(1+r)^{n}}+\frac{n M}{(1+r)^{n}}\right] \frac{1}{P}$

If we now divide the expression in brackets in the equation (6) with the price $P$, we can obtain a new expression which represents definition of the Macaulay duration, measured in years:

$D=\frac{\frac{1 C}{(1+r)}+\frac{2 C}{(1+r)^{2}}+\cdots+\frac{n C}{(1+r)^{n}}+\frac{n M}{(1+r)^{n}}}{P}$

The previous equation may be simplified in the following manner:

$D=\frac{\sum_{n=1}^{N} \frac{n C_{n}}{(1+r)^{n}}}{P}$

Where $\mathrm{Cn}$ is the cash inflow from the bond in time $\mathrm{n}$.

If the expression for the Macaulay duration (7) is to be replaced into the equation (6) which is the calculation for approximate percentage price change, then we obtain the expression for modified duration as follows:

$\frac{d P}{d r} \cdot \frac{1}{P}=-\frac{1}{(1+r)} D=\frac{D}{(1+r)}=-M D(9)$

Or

$M D=\frac{D}{(1+r)}$

The procedure for calculation of the Macaulay duration may be shortened, if the equation for calculation of the bond price (1) is expressed in the following way:

$P=C\left[\frac{1-\frac{1}{(1+r)^{n}}}{r}\right]+\frac{M}{(1+r)^{n}}$ 
$M D=\frac{\frac{C}{r^{2}}\left[1-\frac{1}{(1+r)^{n}}\right]+\frac{n\left(M-\frac{C}{r}\right)}{(1+r)^{n+1}}}{P}$

Glavni nedostatak trajanja obveznica je pretpostavka paralelnog pomaka krivulje prinosa, jer trajanje zavisi od sledećih faktora: (1) ročnosti obveznice, tj. što je ročnost duža veći je uticaj promene kamatnih stopa na cenu obveznice; (2) što je veći kupon to je manje trajanje obveznice; (3) što je viši tržišni prinos to je niže trajanje, odnosno promena kamatnih stopa za 1\% ima manji efekat na cenu obveznica kada su prinosi visoki; (4) konveksnosti - koja predstavlja meru koja pokazuje promenu cene obveznice u odnosu na prinos obveznice; (5) linearna veza promene prinosa i promene cena, odnosno pretpostavlja se da je promena cena ista za rast prinosa od $1 \%$, kao i za pad prinosa od 1\%; (6) cena obveznice kreće se po više ili manje konveksnoj krivulji; (7) Basic point value je promena tržišne vrednosti obveznice ili tržišnog portfolija zbog promene tržišnih kamatnih stopa za jedan basis point; i (8) statističkih metoda procene rizičnosti portfolija na osnovu kretanja cena u prošlosti.

Iako je uobičajeno da manje upućeni na tržištu smatraju da je trajanje zamenska vrednost za vreme dospeća, postoji mogućnost da se ovakvim tumačenjem propusti glavna svrha trajanja, koja se odnosi na meru volatilnosti cena u odnosu na kamatni rizik. Korišćenjem svojstva Macaulay-jevog trajanja može se izvesti mera osetljivosti cene obveznice na kamatne stope, tj. koliko je cena obveznice osetljiva na promene njenog prinosa. Ova mera se dobija primenom matematičkog svojstva poznatog kao Taylor-ova ekspanzija do osnovne jednačine (engl. Taylor's expansion). Odnos između osetljivosti cene i trajanja može se pojasniti ako se jednačina za cenu obveznice, posmatrana kao funkcija od r, proširi kao Taylor-ovi redovi. Koristeći prvi izraz ovog reda, odnos se može izraziti kao:
$\Delta P=-\left[\frac{1}{(1+r)}\right] \times$ Macaulayjevo trajanje $\times$ Promena prinosa

gde je: $r$ - prinos do dospeća obveznice $s$ godišnjom isplatom kupona. Kao što je naznačeno iznad, Macaulay-jevo trajanjejednako je modifikovanom trajanju pomnoženom sa $(1+r)$. Prve dve komponente na desnoj strani jednačine (13), uzete zajedno predstavljaju ekvivalent modifikovanom trajanju, a jednačina (13) predstavlja približnu procentnu promenu cene, koja se izražava preko modifikovanog trajanja pomnoženog sa promenom prinosa. Modifikovano trajanje meri prosečnu promenu $\mathrm{u}$ ceni obveznice za $1 \%$ promene u prinosu na obveznicu. Prema tome, odnos između modifikovanog trajanja i cena obveznica može se izraziti kao:

$\Delta P=-M D \times(\Delta r) \times P(14)$

Negativan predznak $\mathrm{u}$ ovoj jednačini se koristi zato što je kretanje cene inverzno kretanju kamatne stope, tako da rast prinosa dovodi do pada cena i obrnuto. Vrednost baznog poena obveznice (engl. basic point value - $B P V)$, izražava se na sledeći način: ${ }^{1}$

$B P V=\frac{M D}{100} \times \frac{P}{100}$

Da bi zaštita od rizika bila uspešna, promena cene osnovnog instrumenta treba da bude jednaka promeni cene hedžing instrumenta. Za izračunavanje koliko hedžing instrumenta je potrebno da bi se dobio ovaj vid zaštite, koristi se vrednost baznog poena. Prema tome, da bi se zaštitila duga pozicija obveznice (engl. long position $)^{2}$, npr. kod obveznice nominalne vrednosti od 1 milion USD i rokom dospeća od 30 godina, ne može se jednostavno prodati druga obveznica nominalne vrednosti takođe od 1 milion USD i rokom dospeća od 30

1 Vrednost baznog poena koristi se pri zaštiti od rizika pozicije obveznice. Zaštita od rizika se sprovodi tako što se zauzima suprotna pozicija, tj ona čija će vrednost rasti pod istim onim uslovima, koji će dovesti do toga da vrednost pozicije obveznice zaštićene od rizika padne, i obrnuto.

2 Za investitore koji zaključuju ugovor i na osnovu kojeg pristaju na kupovinu neke hartije od vrednosti po određenoj ceni, kaže se da su u dugoj poziciji, što naprosto znači da oni očekuju da će cena posmatrane imovine porasti te da će tako ostvariti zaradu. 
If we are to differentiate the previous equation by means of the first derivation and divide it with the spot bond price $\mathrm{P}$, we obtain the expression as an alternative equation for modified duration:

$M D=\frac{\frac{C}{r^{2}}\left[1-\frac{1}{(1+r)^{n}}\right]+\frac{n\left(M-\frac{C}{r}\right)}{(1+r)^{n+1}}}{P}$

The main drawback of the bond duration is the assumption of a parallel shift in the yield curve, as the duration depends on the following factors: (1) bond maturity, i.e. the longer maturity the higher impact of the interest rates change on the bond price; (2) the higher the coupon, the lower is bond duration; (3) the higher the market yield, the lower is the duration, i.e. the change in the interest rates for $1 \%$ has lower effect on the bond price when the yield is high; (4) convexity - which is the measure indicating the change in the bond price in respect to the bond yield; (5) linear connection between yield and price change, i.e. assumption that the price change is the same for yield growth of $1 \%$ and for the yield fall of $1 \%$; (6) bond price moves along a more or less convex curve; (7) Basis point value is the change in the bond market value or market portfolio, due to the change in the market interest rates, for one basis point; and (8) statistical portfolio risk assessment methods based on the price movement history.

Although it is usual for those less versed in the market to deem the duration as a substitute value for maturity term, there is a possibility with such an interpretation to miss the main purpose of duration, which pertains to the price volatility measure in respect to the interest risk. By applying properties of the Macaulay duration it is possible to derive the measure of bond price sensitivity to the interest rates, i.e. to find out how much is the bond price sensitive to the change in its yield. This measure is obtained by applying the mathematical feature known as the Taylor's expansion up to the basic equation.
The ratio between price sensitivity and duration may be clarified if the bond price equation, observed as the function of $r$, is expanded as the Taylor expansion rows. Using the first expression of this row, the ratio may be expressed as follows:

$\Delta P=-\left[\frac{1}{(1+r)}\right] \times$ Macaulay duration $\times$ Yield change

Where $\mathrm{r}$ is yield (return) on bond maturity, with annual coupon payment.

As mentioned herein above, Macaulay duration is equal to the modified duration multiplied by $(1+r)$. The first two components on the right-hand side of the equation (13), when taken together, represent an equivalent to the modified duration, and the equation (13) represents an approximate percentage price change, which is expressed through the modified duration multiplied by yield change. Modified duration measures average change in the bond price for $1 \%$ of change in the bond yield. Therefore, the ratio between modified duration and the bond price may be expressed as follows:

$\Delta P=-M D \times(\Delta r) \times P(14)$

Negative sign in this equation is used because the price movement is the inverse interest rate movement, so that the yield growth causes the price fall and vice versa. The basis point value - BPV of a bond is expressed in the following manner:

$B P V=\frac{M D}{100} \times \frac{P}{100}$

In order to have successful risk protection, the change in price of the underlying instrument should be equal to the change in price of the hedging instrument. For the calculation of how many hedging instruments are necessary in order to obtain this form of protection, the basis point value is used. Therefore in order to

1 Basis point value is used as protection against the risk of the bond's position. The risk protection is implemented by taking the opposite position, i.e. the one whose value would increase under the same conditions, leading to the decreased value of the position of the risk-protected bond, and vice versa. 
godina. Druga obveznica s rokom dospeća od možda jednostavno nije na raspolaganju. Da bi se izračunalo koliki je nominalni iznos hedžing obveznice potreban, koristi se optimalni koeficijent hedžiranja (engl. hedge ratio):

$\frac{B P V_{p}}{B P V_{k}} \times \frac{\text { Promena u prinosu za osnovnu poziciju obveznice }}{\text { Promena u prinosu za hedžing instrument }}$ (16)

gde je $B P V_{p}$ - vrednost baznog poena osnovne obveznice (pozicija koju treba hedžirati) i $B P V_{k}$ - vrednost baznog poena hedžing instrumenta. 30 godina i istom vrednošću baznog poena

Nedostatak trajanja se ogleda u činjenici da odnos cene i prinosa čak i kod standardnih kuponskih obveznica nije linearan. Tako dugoročne državne obveznice imaju konveksan profil, dok opozive obveznice i hipotekarne obvezniceimaju blagokonkavan profil, tj. pojavu poznatu kao negativna konveksnost. Stoga je modificirano trajanje dobra aproksimacija za obveznice sa fiksnim kuponom i dospećem, ali neodgovarajuća mera za obveznice koje pokazuju određenu neizvesnost $\mathrm{u}$ novčanim tokovima i dospeću.

Za svaku obveznicu, modifikovano trajanje postaje rastuće

Tabela 2: Aproksimacija modifikovanog trajanja promjene cene obveznice pri različitim prinosima

\begin{tabular}{|l|r|r|r|r|r|r|}
\hline \multicolumn{2}{|c|}{} & \multicolumn{5}{|c|}{ Prinos } \\
\hline Obveznica: & $8 \%, 2009$. & $6,00 \%$ & $6,50 \%$ & $7,00 \%$ & $7,50 \%$ & $7,99 \%$ \\
\hline Dospeće: & 10 & $114.720,17$ & $110.783,25$ & $107.023,58$ & $103.432,04$ & $100.06,71$ \\
\hline $\begin{array}{l}\text { Modifikovano } \\
\text { trajanje: }\end{array}$ & $6.766,95$ & $8,00 \%$ & $8,01 \%$ & $8,50 \%$ & $9,00 \%$ & $10,00 \%$ \\
\hline BPV: & 0,06936 & $100.000,00$ & $99.932,93$ & $96.719,33$ & $93.582,34$ & $87.710,87$ \\
\hline
\end{tabular}

Izvor: Choudhry, M. (2010). An Introduction to bond markets, John Wiley and Sons, str. 81. $\mathrm{n}$ e p r e ci z n a mera za rastuću $\mathrm{m}$ a g $\mathrm{n}$ i t u d u p r o m e $n$ e $\mathrm{k}$ a $\mathrm{m}$ a $\mathrm{t} \mathrm{n}$ e stope. Iz datih okolnosti se vrši prilagođavanje procene promene cene upotrebom konveksnosti.
U tabeli 2 u odeljku Prinos, prikazana je promena u ceni za $8 \%$ obveznicu, koja je dospela u 2009. godini. Za promenu u prinosu od 1 baznog poena (bp), promena u ceni obveznice $\mathrm{s}$ obzirom na vrednost baznog poena nije $\mathrm{u}$ potpunosti precizna, što upućuje na zaključak da se radi samo o proceni promene stvarne cene. $\mathrm{Za}$ veće promene, npr. od 200 bp, procena promene cene putem modifikovanog trajanja pokazuje značajnu grešku i analitički je nedostatna. Ovim načinom se potcenjuje promena u ceni uvek kada prinos pada, te se precenjuje promena $u$ ceni onda kada prinos raste. To je rezultat odnosa cena/prinos obveznice date $\mathrm{u}$ ovom primeru. Određene obveznice imaju više izraženu konveksnu vezu između cene i prinosa, tako da modifikovano trajanje potcenjuje promene u ceni i u slučaju rasta i u slučaju pada prinosa.

Tabela 3: Stvarno kretanje cene obveznice naspram procenjenog kretanja cene na bazi modifikovanog trajanja

\begin{tabular}{|l|r|r|}
\hline \multicolumn{1}{|l|}{$\Delta$ YTM } & Stvarna promjena cijene & Promjena po osnovu trajanja (BPV) \\
\hline Dole 1 bazni poen & 0,06713 & 0,06936 \\
\hline Gore 1 bazni poen & 0,06707 & 0,06936 \\
\hline Dole 200 baznih poena & $14.720,17$ & 13.872 \\
\hline Gore 200 baznih poena & $12.289,13$ & 13.872 \\
\hline
\end{tabular}

Trajanje je mera kamatnog rizika prvog reda, koja se dobija primenom izvoda prvog reda. Ako se odnos cene i prinosa prikaže na grafikonu, formira se krivulja, a trajanje ukazuje na nagib tangente u bilo kojoj tački ove krivulje. Međutim, tangenta je linija i kao takva, samo je aproksimacija stvarne krivulje - aproksimacija koja postaje sve manje tačna kako prinos obveznice sve dalje odmiče od prvobitne tačke. Štaviše, opseg greške zavisi od zakrivljenosti ili konveksnosti krivulje. Konveksnost predstavlja pokušaj da se isprave manjkavosti trajanja. Alternativne teorije vremenske strukture kamatnih stopa dovele su do alternativnih definicija trajanja, tj. do alternativnih strategija imunizacije. Naime, već nekoliko strategija pokazalo je da alternativne strategije imunizacije ne daju ništa bolje rezultate. $\mathrm{Na}$ primer, Bierwag et al. (1981) zaključili su da jednostavna strategija bazirana na Macaulayevom trajanju imunizira portfolio jednako dobrokaoistrategije 
protect bond long position, for example in case of a bond with the nominal value of 1 million USD and the maturity of 30 years, it is not possible to simply sell some other bond of the nominal value of also 1 million USD and the maturity of 30 years. The other bond with the maturity of 30 years and the same basis point value may simply not be available. In order to calculate the nominal amount of the hedging bond that is necessary, the optimum hedge ratio is used:

$\frac{B P V_{p}}{B P V_{k}} \times \frac{\text { Promena u prinosu za osnovnu poziciju obveznice }}{\text { Promena u prinosu za hedžing instrument }}$

Where: $B V P_{p}$ is the basis point value of the underlying bond (position that needs hedging), and the $B V P_{k}$ is the basis point value of the hedging instrument. underestimates changes in price both in the case of growth and in the case of fall of yield.

Table 3: Real bond price movement with respect to the estimated price movement on the basis of modified duration

\begin{tabular}{|l|r|r|}
\hline$\Delta$ YTM & $\begin{array}{c}\text { Real price } \\
\text { change }\end{array}$ & $\begin{array}{c}\text { Change based of } \\
\text { duration (BPV) }\end{array}$ \\
\hline Down 1 basis point & 0.06713 & 0.06936 \\
\hline Up 1 basis point & 0.06707 & 0.06936 \\
\hline Down 200 basis point & $14,720.17$ & 13,872 \\
\hline Up 200 basis point & $12,289.13$ & 13,872 \\
\hline
\end{tabular}

Source: Choudhry, M. (2010). An Introduction to bond markets, John Wiley and Sons, p. 82.

The drawback of duration is reflected in the fact that the price/yield ratio even with
Table 2: Approximation of the modified duration of the bond price change with different yields

\begin{tabular}{|l|r|r|r|r|r|r|}
\hline \multicolumn{2}{|c|}{} & \multicolumn{5}{|c|}{ Yield } \\
\hline Bond & $8 \%, 2009$ & $6.00 \%$ & $6.50 \%$ & $7.00 \%$ & $7.50 \%$ & $7.99 \%$ \\
\hline Maturity & 10 & $114,720.17$ & $110,783.25$ & $107,023.58$ & $103,432.04$ & $100,06.71$ \\
\hline $\begin{array}{l}\text { Modified } \\
\text { duration }\end{array}$ & $6,766.95$ & $8.00 \%$ & $8.01 \%$ & $8.50 \%$ & $9.00 \%$ & $10.00 \%$ \\
\hline BVP: & 0.06936 & $100,000.00$ & $99,932.93$ & $96,719.33$ & $93,582.34$ & $87,710.87$ \\
\hline
\end{tabular}

Source: Choudhry, M. (2010). An Introduction to bond markets, John Wiley and Sons, str. 81.

standard coupon bonds is not linear. Thus the longterm government bonds are having a convex profile, while callable bonds and mortgage bonds are having a slightly concave profile,

In Table 2, under heading Yield, the change in price is presented for $8 \%$ yield bond, which matured in 2009. For the change in yield of 1 basis point (bp) the change in bond price with respect to the basis point is not fully precise, which leads to the conclusion that it is only an estimate of the change in real price. For larger changes, for example of $200 \mathrm{bp}$, estimate of the price change through the modified duration shows a significant error and is analytically incomplete. In this way the price change is underestimated always when the yield falls, and the price change is overestimated when the yield grows. This is the result of the price/yield ratio of the bond given in this example. Certain bonds have a more pronounced convex link between price and yield, so that the modified duration i.e. the phenomenon known as the negative convexity. Hence the modified duration is a good approximation for the fixed coupon and maturity bonds, while it is not an adequate measure for bonds showing some uncertainty in cash flows and maturity.

For every bond modified duration becomes increasingly imprecise measure for the growing magnitude of change in the interest rate. On the basis of the given circumstances, adjustment is made of the price change estimate by the use convexity. Duration is the interest rate risk measure of the first order, which is obtained by the application of the derivation of the first order. If the price/yield ratio is to be presented on a graph, a curve is formed, and the duration indicates at the inclination

2 The investors concluding the contract based on which they agree to purchase a security at the arranged price, are said to be in the long position, which simply means that they expect the price of the concerned asset to increase, thereby bringing them profit. 
bazirane na mnogo složenijim merama trajanja i da je ujedno troškovno najuspešnija.

\section{Tendencija kretanja na tržištu obveznica u Bosne i Hercegovine}

I pored toga što su u 2009. godini u trgovinu na Sarajevskoj berzi (SASE) uvrštene prve serije obveznica ratnih potraživanja i stare devizne štednje FBiH, država (entitet) se nije direktno pojavljivala kao učesnik na tržištu kapitala. Prva opština u $\mathrm{FBiH}$ koja je prepoznala prednosti obveznica i učinila prvi pionirski korak za svoj dalji razvoj je opština Tešanj. Emisijom obveznica u 2011. godini, prikupila je EUR.
255.646 za uređenje poslovne zone. Druga opština u FBiH koja je iskoristila ovaj način finansiranja svoga razvoja je Opština Cazin, koja je u 2012. godini na tržištu prikupila EUR. 511.292. Obveznice stare devizne štednje imaju relativno kratak rok dospeća, te je i njihova cena na tržištu obveznica veća, u odnosu na obveznice ratnih potraživanja. Sve obveznice stare devizne štednje isplaćuju 2,5\% kamate na godišnjem nivou, uz polugodišnje isplate. Dakle, potencijalni investitor ima dva izvora zarade, i to: dospele kamate i kapitalnu dobit obveznice (razliku između cene po kojoj je kupio i po kojoj je prodao obveznicu).

Tabela 4: Obveznice FBiH - stara devizna štednja

\begin{tabular}{|l|r|r|r|r|r|}
\hline Simbol & $\begin{array}{c}\text { Broj emitovanih } \\
\text { obveznica }\end{array}$ & $\begin{array}{c}\text { Nominalna } \\
\text { vrijednost (EUR) }\end{array}$ & $\begin{array}{c}\text { Datum } \\
\text { emisije }\end{array}$ & $\begin{array}{c}\text { Datum } \\
\text { dospeća }\end{array}$ & $\begin{array}{c}\text { Kamatna } \\
\text { stopa }\end{array}$ \\
\hline FBIHKE & 51.974 .194 & 0,51 & 30.09 .2009$. & 30.09 .2013$. & $2,50 \%$ \\
\hline FBIHKF & 60.689 .179 & 0,51 & 30.09 .2009$. & 30.09 .2014$. & $2,50 \%$ \\
\hline FBIHKJ & 5.046 .095 & 0,51 & 30.03 .2010$. & 30.09 .2013$. & $2,50 \%$ \\
\hline FBIHKK & 5.046 .549 & 0,51 & 30.03 .2010$. & 30.09 .2014$. & $2,50 \%$ \\
\hline FBIHKL & 12.202 .078 & 0,51 & 30.03 .2010$. & 30.09 .2015$. & $2,50 \%$ \\
\hline FBIHKN & 30.724 .738 & 0,51 & 31.03 .2011$. & 31.03 .2013$. & $2,50 \%$ \\
\hline FBIHKO & 31.102 .714 & 0,51 & 31.03 .2011$. & 31.03 .2014$. & $2,50 \%$ \\
\hline FBIHKP & 50.739 .958 & 0,51 & 31.03 .2011$. & 31.03 .2015$. & $2,50 \%$ \\
\hline FBIHKR & 89.649 .900 & 0,51 & 31.03 .2011$. & 31.03 .2016$. & $2,50 \%$ \\
\hline FBIHKT & 9.886 .007 & 0,51 & 31.03 .2012$. & 31.08 .2013$. & $2,50 \%$ \\
\hline FBIHKU & 9.982 .190 & 0,51 & 31.03 .2012$. & 31.08 .2014$. & $2,50 \%$ \\
\hline FBIHKV & 19.868 .669 & 0,51 & 31.03 .2012$. & 31.08 .2015$. & $2,50 \%$ \\
\hline FBIHKZ & 25.579 .944 & 0,51 & 31.03 .2012$. & 31.08 .2016$. & $2,50 \%$ \\
\hline
\end{tabular}

Izvor: Kurbegović, T., Mirica, A., Martinčević, A. (2012). Povezivanje tržišta kapitala u uslovima globalizacije - sedma Međunarodna konferencija, Sarajevska berza, Sarajevo, str. 39. 
of the tangent in any one point of this curve. However, tangent is the line and as such it is only an approximation of the real curve - an approximation which becomes less and less precise as the bond yield is further shifted from the original point. In addition, the scope of error depends on the curvature or convexity of the curve. Convexity is an attempt to rectify the shortcomings of the duration. Alternative theories of the time structure of interest rates have led to the alternative definitions for the duration, i.e. to the alternative strategies of immunization. Namely, several strategies have already shown that the alternative immunization strategies are not yielding any better results. For example, Bjerwag et al. (1981) have concluded that the simple strategy based on Macaulay duration is immunizing portfolio just as well as strategies based on much more complex duration measures, and that it is also the most cost effective.

\section{The bonds market movement tendencies in Bosnia and Herzegovina}

In spite of the fact that in 2009 on the Sarajevo Stock Exchange (SASE) the first series of bonds for war reparations and the old foreign currency savings of $\mathrm{FBiH}$ has been listed for trading, the state (entity) did not directly appear as a participant on the capital market. The first municipality in $\mathrm{FBiH}$ to recognize the advantages of bonds and make the first pioneering step towards its further development was the municipality of Tesanj. By issuing bonds in 2011, it collected the sum of EUR 255,646 for the regulation of its business zone. The second municipality in $\mathrm{FBiH}$ that availed itself of this manner of financing its development was the Municipality of Cazin, which in 2012 collected on the market the amount EUR 511,292. The old foreign currency savings bonds have a rather short maturity term, so that their price on the bond market is rather higher, in respect to the bonds for war reparations. All the bonds of the old foreign currency savings are paying $2.5 \%$ interest annually, with semi-annual payments. Hence, potential investors have two sources of earning, as follows: matured interest and the capital gain on bonds (difference between the purchase price and the selling price of bond).

Table 4: FBiH bonds - Old foreign currency savings

\begin{tabular}{|l|r|r|r|r|r|}
\hline Symbol & \multicolumn{1}{|c|}{$\begin{array}{c}\text { Number of } \\
\text { bonds issued }\end{array}$} & $\begin{array}{c}\text { Nominal value } \\
\text { (EUR) }\end{array}$ & Date of issue & \multicolumn{1}{c|}{$\begin{array}{c}\text { Maturity } \\
\text { date }\end{array}$} & Interest rate \\
\hline FBIHKE & $51,974,194$ & 0.51 & 30.09 .2009 & 30.09 .2013 & $2.50 \%$ \\
\hline FBIHKF & $60,689,179$ & 0.51 & 30.09 .2009 & 30.09 .2014 & $2.50 \%$ \\
\hline FBIHKJ & $5,046,095$ & 0.51 & 30.03 .2010 & 30.09 .2013 & $2.50 \%$ \\
\hline FBIHKK & $5,046,549$ & 0.51 & 30.03 .2010 & 30.09 .2014 & $2.50 \%$ \\
\hline FBIHKL & $12,202,078$ & 0.51 & 30.03 .2010 & 30.09 .2015 & $2.50 \%$ \\
\hline FBIHKN & $30,724,738$ & 0.51 & 31.03 .2011 & 31.03 .2013 & $2.50 \%$ \\
\hline FBIHKO & $31,102,714$ & 0.51 & 31.03 .2011 & 31.03 .2014 & $2.50 \%$ \\
\hline FBIHKP & $50,739,958$ & 0.51 & 31.03 .2011 & 31.03 .2015 & $2.50 \%$ \\
\hline FBIHKR & $89,649,900$ & 0.51 & 31.03 .2011 & 31.03 .2016 & $2.50 \%$ \\
\hline FBIHKT & $9,886,007$ & 0.51 & 31.03 .2012 & 31.08 .2013 & $2.50 \%$ \\
\hline FBIHKU & $9,982,190$ & 0.51 & 31.03 .2012 & 31.08 .2014 & $2.50 \%$ \\
\hline FBIHKV & $19,868,669$ & 0.51 & 31.03 .2012 & 31.08 .2015 & $2.50 \%$ \\
\hline FBIHKZ & $25,579,944$ & 0.51 & 31.03 .2012 & 31.08 .2016 & $2.50 \%$ \\
\hline
\end{tabular}

Source: Kurbegović, T., Mirica, A., Martinčević, A. (2012). Povezivanje tržišta kapitala u uslovima globalizacije (Linking of the capital markets in the light of globalization) The Seventh International Conference, Sarajevo Stock Exchange, p. 39 
Prema podacima Registra vrednosnih papira u FBiH, oko 5\% obveznica stare devizne štednje je promenilo vlasnika. Dakle, ovo navodi na zaključak da dosta vlasnika nije informisano o mogućnostima koje imaju od posedovanja obveznica, što je s druge strane i razumljivo obzirom da su vlasnici uglavnom osobe starije životne dobi koje nemaju iskustva s tržištem kapitala.

Broj hartija od vrednosti kojima se trgovalo u 2012. godini, u odnosu na 2011. godinu smanjio se, što se nije odrazilo na vrednost ostvarenog prometa. Dakle, nakon velikih padova svih parametara trgovanja u 2008. godini, te broja trgovanih hartija od vrednosti u 2009. godini, zabeležen je rast ukupnog broja trgovanih hartija od vrednosti zahvaljujući pre svega trgovini obveznicama FBiH koje su kako je već i naglašeno po prvi put emitovane i uvrštene $\mathrm{u}$ trgovanje. U nastavku teksta daje se prikaz učešća akcija i obveznica u ukupnom prometu u 2012. godini, kako na Sarajevskoj tako i na Banjalučkoj berzi. način da podelimo vrednost prometa i količinu trgovanih hartija od vrednosti, dobijamo da je prosečna vrednost jedne akcije EUR. 5,13 po akciji, dok je prosečna cena obveznica EUR. 0,31. Prosečna vrednost jedne akcije na BLSE iznosi EUR. 0,17 i EUR. 0,41 obveznica i trezorskih zapisa. Daljom komparacijom ostvarenog prometa na SASE s prometom na BLSE dolazimo do podatka da je vrednost prometa na SASE za posmatrani period veća od prometa ostvarenog na BLSE dve godine za redom. Rezultat toga je u značajnom meri realizacija javnih ponuda dužničkih hartija od vrednosti putem berze. Na SASE je u 2012. godini uspešno okončano 11 primarnih emisija dužničkih hartija od vrednosti u ukupnom iznosu od EUR. 128.153.493, dok je na BLSE realizovana vrednost primarnih emisija dužničkih hartija od vrednosti u iznosu od EUR. 67.004.257. Dakle, značajno veća vrednost realizovanih ponuda emisije vrednosnih papira na SASE je $\mathrm{u}$ istoj meri pozitivno uticala i na povećanje prometa, gde je promet na SASE

Tabela 5: Prikaz učešća akcija i obveznica u ukupnom prometu na SASE i BLSE u 2012. godini (u mil. EUR)

\begin{tabular}{|c|c|c|c|c|c|c|c|c|c|c|}
\hline \multirow{3}{*}{$\begin{array}{l}\text { Pokazatelji } \\
\text { Vrednost }\end{array}$} & \multicolumn{5}{|c|}{ Sarajevska berza vrednosnih papira (SASE) } & \multicolumn{5}{|c|}{ Banjalučka berza hartija od vrednosti (BLSE) } \\
\hline & \multicolumn{2}{|c|}{ Akcije } & \multicolumn{2}{|c|}{ Obveznice } & \multirow{2}{*}{$\begin{array}{c}\text { Ukupno } \\
50.060 .326\end{array}$} & \multicolumn{2}{|c|}{ Akcije } & \multicolumn{2}{|c|}{ Obveznice } & \multirow{2}{*}{$\begin{array}{l}\text { Ukupno } \\
52.454 .915\end{array}$} \\
\hline & 42.025 .447 & $84 \%$ & 8.034 .879 & $16 \%$ & & 19.161.100 & $37 \%$ & 33.293 .815 & $63 \%$ & \\
\hline $\begin{array}{l}\text { Broj } \\
\text { hartija od } \\
\text { vrednosti }\end{array}$ & 8.184 .730 & $24 \%$ & 26.065 .447 & $76 \%$ & 34.250 .177 & 110.884 .327 & $58 \%$ & 81.474 .823 & $42 \%$ & 192.359 .150 \\
\hline $\begin{array}{l}\text { Broj } \\
\text { transakcija }\end{array}$ & 8.879 & $79 \%$ & 2.392 & $21 \%$ & 11.271 & 15.139 & $57 \%$ & 11.568 & $43 \%$ & 26.707 \\
\hline
\end{tabular}

Izvor: http://www.komvp.gov.ba, Izvještaj o radu Komsije za vrijednosne papire Federacije BiH za 2012. godinu, str. 19.

Iz prethodne tabele se jasno vidi da udeo akcija u ukupnoj vrednosti prometa na SASE zauzima značajnije učešće od vrednosti prometa dužničkih hartija od vrednosti, što i nije slučaj na BLSE, gde je vrednost prometa dužničkih hartija od vrednosti skoro pa duplo veća od prometa akcija. Ovo nije bio slučaj prethodne godine, kada su dominantnu ulogu u ukupnoj vrednosti prometa imale akcije i na SASE i na BLSE. Ako iz prethodne tabele izračunamo prosečnu cenu trgovanja hartija od vrednosti na u odnosu na BLSE bio veći za oko 43,17\%. Na oscilacije ukupno ostvarenog prometa na BLSE po mesecima u 2012. godini značajno su uticale javne ponude obveznica $i$ javne ponude trezorskih zapisa u prometu u 2011. godini. U 2012. godini na finansijskom tržištu FBiH je usledilo i prvo izdanje entitetskih obveznica za pokriće budžetskih obaveza kroz ukupno tri emisije prikupljeno je 66 miliona EUR, gde je Sarajevska berza za ove emisije kreirala posebnu vrstu aukcije, tzv. prinosnu aukciju. ${ }^{3}$ 
According to the FBiH Securities Register, some $5 \%$ of bonds on the old foreign currency savings have changed the holders. Hence, this leads to the conclusion that many of the holders were not well informed on the options that the bonds holding offers, which on the other hand is understandable in view of the fact that the bonds holders are mostly elderly persons without sufficient experience with the capital market.

The number of securities traded in 2012, in comparison with 2011, has fallen, but did not impact the value of the trading conducted. Therefore, after some major falls in all the trading parameters in 2008 and the number of securities traded in 2009, growth was recorded in the total number of securities traded thanks primarily to the trading in the $\mathrm{FBiH}$ bonds which were, as already mentioned, issued for the first time and listed for trading. Further in this paper we are giving the presentation of the share of stocks and bonds in the total trading in 2012, both on the Sarajevo and on the Banja Luka stock exchanges. traded, we obtain the result showing that the average value of one stock is EUR 5.13 per stock, while the average price of bonds is EUR 0.31. The average value of one stock on the BLSE is EUR 0.17 and EUR 0.41 of bonds and treasury bills. Further comparison of trading made on the SASE and on the BLSE leads us to the fact that the value of trade on the SASE, during the observed period, was higher than the value of trade on the BLSE for two consecutive years. The result of this is to a considerable extent the realization of public offers of the debt securities through the stock exchange. On the SASE, in 2012, there was a successful completion of 11 primary issues of the debt securities in the total value of EUR 128,153,493, while on the BLSE the realized value of primary issues of debt securities was in the value of EUR 67,004,257. Therefore, significantly higher value of realized offers of issued securities on the SASE has to the same extent had a positive impact both on the boost of trading, where the trading on SASE in respect to the BLSE was higher for

Table 5: Share of stocks and bonds in the total trading on the SASE and the BLSE in the year 2012 (in mil. EUR)

\begin{tabular}{|c|c|c|c|c|c|c|c|c|c|c|}
\hline \multirow{3}{*}{$\begin{array}{l}\text { Indcators } \\
\text { Value }\end{array}$} & \multicolumn{5}{|c|}{ Sarajevo Stock Exchange (SASE) } & \multicolumn{5}{|c|}{ Banja Luka Stock Exchange (BLSE) } \\
\hline & \multicolumn{2}{|c|}{ Stocks } & \multicolumn{2}{|c|}{ Bonds } & \multirow{2}{*}{$\begin{array}{c}\text { Total } \\
50,060,326\end{array}$} & \multicolumn{2}{|c|}{ Stocks } & \multicolumn{2}{|c|}{ Bonds } & \multirow{2}{*}{$\begin{array}{c}\text { Total } \\
52,454,915\end{array}$} \\
\hline & $42,025,447$ & $84 \%$ & $8,034,879$ & $16 \%$ & & $19,161,100$ & $37 \%$ & $33,293,815$ & $63 \%$ & \\
\hline $\begin{array}{l}\text { Number of } \\
\text { securities }\end{array}$ & $8,184,730$ & $24 \%$ & $26,065,447$ & $76 \%$ & $34,250,177$ & $110,884,327$ & $58 \%$ & $81,474,823$ & $42 \%$ & $192,359,150$ \\
\hline $\begin{array}{l}\text { Number of } \\
\text { Transactions }\end{array}$ & 8,879 & $79 \%$ & 2,392 & $21 \%$ & 11,271 & 15,139 & $57 \%$ & 11,568 & $43 \%$ & 26,707 \\
\hline
\end{tabular}

Source: http://www.komvp.gov.ba,Report on the work of Securities Commission of the Federation of Bosnia and Herzegovina for 2012, p. 19

The above Table clearly shows that the proportion of stocks in the total value of trading on the SASE is having a more significant share than the value of trade in debt securities, which is not the case on the BLSE, where the value of debt securities trading is almost double in size than the trade in stocks. This was not the case in the previous year as the dominant role in the total value of trade was played by stocks both on the SASE and on the BLSE. If we are to calculate from the above Table the average price of trading in securities, by dividing the value of trading with the amount of securities some $43.17 \%$. On the oscillations in the totally realized trading on the BLSE per months of 2012 significant impact was made by the public offer of bonds and the public offer of treasury bills during trading in 2011. In 2012, on the financial market of the $\mathrm{FBiH}$ what occurred was also the first issue of the entity bonds for covering budgetary liabilities through a total of three issues, where 66 million EUR was collected, when the Sarajevo Stock Exchange created for these issues a special type of auction, the socalled yield auction. Under the decision of the Government of FBiH of 21 October 2009, the 
Po osnovu odluke Vlade FBiH od 21.10.2009. godine, izdato je prvih šest serija obveznica stare devizne štednje. Ukupna suma prve emisije je iznosila preko 177 miliona eura, s rokom dospeća od 2009. do 2014. Do danas su uvrštene još tri emisije obveznica ukupne vrednosti 176 miliona eura.

\section{Podaci za analizu}

Kao što je i rečeno trajanje zapravo predstavlja elastičnost cene obveznice s obzirom na promenu kamatnog faktora, odnosno objašnjava za koliko će se cena obveznice smanjiti ako se kamatni faktor poveća za $1 \%$. Što je veće trajanje određene hartije od vrednosti (obveznice) potrebno je više vremena da potencijalni investitor povrati uloženi novac. Obveznice koje će biti predmet ovog istraživanja su: (1) Municipalne obveznice Opštine Bijeljina (simbol: BNIF - O - A); (2) Obveznice stare devizne štednje (simbol: FBIHKR); (3) Obveznice Federacije $\mathrm{BiH}$ (simbol: FBIHK3A); (4) Atlantik BB Banja Luka (simbol: ATFR O - A); (5) Obveznice FBiH (treća serija) i (6) Obveznice $\mathrm{FBiH}$ (simbol: FBIHK4A).

Na Sarajevskoj berzi hartija od vrednosti zaključno sa 09.08.2013. godine, ostvaren je ukupan promet obveznicama od 98,12 hiljada eura, uz učešće u ukupnom prometu od 56,91\%. Promet obveznicama stare devizne štednje iznosio je 72,7 hiljade eura, gde je najveći promet zabeležen serijom R obveznica stare devizne štednje (FBIHKR) u iznosu od 22,7 hiljade eura, uz prosečan prinos po dospeću (engl. yield to maturity - YTM) od $4,51 \%$. Tržišna cena ove serije obveznica je zabeležila manji pad u vrednosti u odnosu na prethodnu sedmicu, gde je trgovano po ceni od 95,06\% (od nominalne vrednosti) na poslednji dan trgovanja. Najveći prinos po dospeću kod obveznica stare devizne štednje beleži serija J uz YTM od 9,29\%. Promet obveznicama na Banjalučkoj berzi za isti period iznosio je 212,4 hiljade eura, što predstavlja 52\% ukupno ostvarenog prometa na berzi. Za period od 10.08. 2009. do 30.06.2013. godine obveznice Opštine Bijeljina su imale ukupnu vrednost prometa od EUR. 758.891, standardnu devijaciju od 0,02\% te prosečnu cenu za izabrani period od 100,15\%.

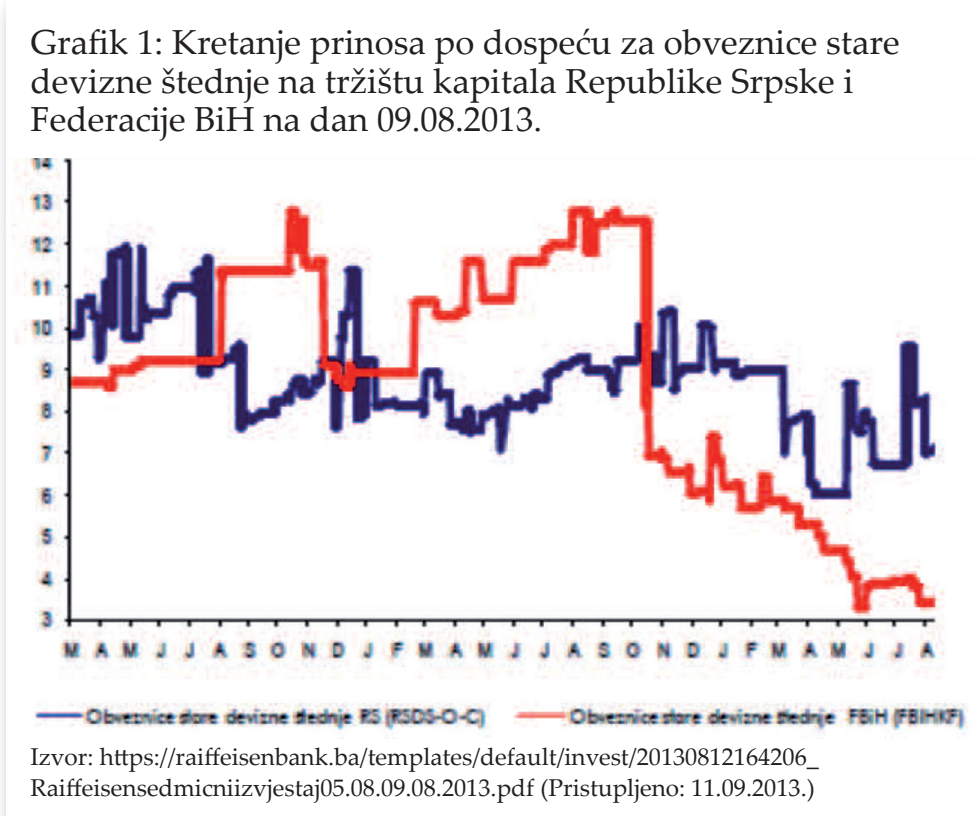

Grafik 1: Kretanje prinosa po dospeću za obveznice stare izne stednje na tržistu kapitala Republike Srpske i

Na osnovu nominalne vrednosti, godišnje kamatne stope, datuma dospeća i cena obveznica te primenom jednačine (8) došlo se do sledećih rezultata trajanja obveznica, što ilustruje sledeća tabela.

3 Prinosna aukcija omogućava investitoru da u sistem unese traženi prinos na godišnjem nivou, gde kada se emitent odredi o prihvatljivoj ceni, prinos se konvertuje u cenu koju će kupac platiti za obveznicu. 
first six series of bonds were issued for the old foreign currency savings. The total amount of the first issue amounted to over 177 million EUR, with the maturity from the year 2009 to 2014. To date, another three issues of bonds have been floated in the total value of 176 million EUR.

\section{Data for analysis}

It was already mentioned that the duration is actually the bond price elasticity with respect to the change in the interest factor, i.e. it explains just how much the bond price will fall if the interest factor grows for $1 \%$. The longer the duration of a certain security (bond), the more time is needed for potential investor to return his invested money. Bonds that are the subject of this research are the following: (1) Municipal bonds of the Municipality of Bijeljina (symbol: BNIF - 0 - A); (2) Bonds of the old foreign currency savings ((symbol: FBIHKR); (3) BiH Federation bonds (symbol: FBIHK3A); (4) Atlantik BB Banja Luka (symbol: ATFR - 0 - A); (5) FBiH bonds (the third series); and (6) FBiH bonds (symbol: FBIHK4A).

On the Sarajevo Stock Exchange and securities market, conclusive with 9 August 2013, the total trading in bonds was conducted in the value of 98.12 thousand EUR, with the share in total trading of $56.91 \%$. Trading in bond of the old foreign currency savings reached 72.7 thousand EUR, where the highest trading was recorded in the series $R$ bonds of the old foreign currency savings (FBIHKR) in the amount of 22.7 thousand EUR, with an average yield to maturity (YTM) of $4.51 \%$. The market price of this bond series recorded a slight fall in value in respect to the previous week, when trading was done at a price of $95.06 \%$ (of the nominal value) on the last day of trading. The highest yield to maturity in the bonds for old foreign currency savings was recorded by the series J with the YTM of 9.29\%. Trading in bonds on the Banja Luka Stock Exchange, over the same period, reached 212.4 thousand EUR, which is $62 \%$ of the total stock exchange trading. During the period from 10 August 2009 to 30 June 2013, bonds of the Municipality of Bijeljina had the total trading value of EUR 758,891, standard deviation of $0.02 \%$, and an average price for the selected period of $100.15 \%$.
Graph 1: Movement of yield to maturity for bonds of the old foreign currency savings on the capital market of the Republic of Srpska and the Federation of $\mathrm{BiH}$, as of 9 August 2013

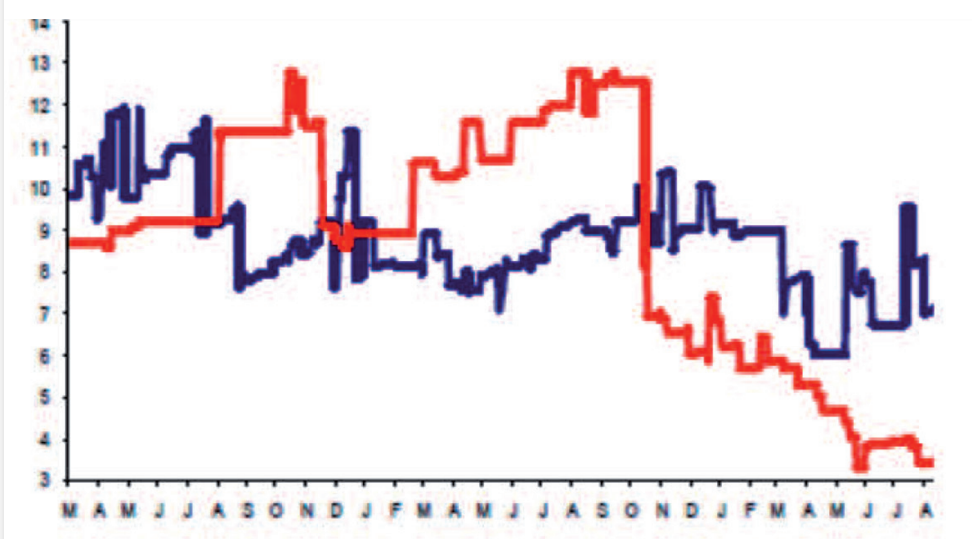
Bonds of the old FX savings of the RS (RSDS-O-C) Bonds of the old FX savings of the FBaH (FBIHKF) Source: https://raiffeisenbank.ba/templates/default/invest/20130812164206_ Raiffeisensedmicniizvjestaj05.08.09.08.2013.pdf (Accessed: 11.09.2013)

3 The revenue auction enables investors to enter the required revenue into the system at the annual level, and when the issuer determines the acceptable price, the revenue is converted into the price the buyer will pay for the bond. 
Tabela 6: Vrednost i trajanje za određene vrste obveznica na finansijskom tržištu BiH

\begin{tabular}{|c|c|c|c|c|c|c|}
\hline $\begin{array}{c}\text { Simbol } \\
\text { obveznice }\end{array}$ & $\begin{array}{c}\text { Vrsta } \\
\text { obveznice }\end{array}$ & $\begin{array}{c}\text { Nominalna } \\
\text { vrednost }\end{array}$ & $\begin{array}{c}\text { Datum emisije } \\
\text { i dospeća } \\
\text { obveznice }\end{array}$ & $\begin{array}{c}\text { Godišnja } \\
\text { kamatna } \\
\text { stopa }\end{array}$ & $\begin{array}{c}\text { Cena } \\
\text { obveznice }\end{array}$ & $\begin{array}{c}\text { Trajanje } \\
\text { (duracija) } \\
\text { obveznice }\end{array}$ \\
\hline BNIF-O-A & $\begin{array}{l}\text { Municipalne } \\
\text { obveznice } \\
\text { Opština } \\
\text { Bijeljina }\end{array}$ & 51,13 & $\begin{array}{c}10.08 .2009 . \\
10.08 .2019 .\end{array}$ & $6,75 \%$ & 51,13 & 7,58 \\
\hline FBIHKR & $\begin{array}{l}\text { Obveznice } \\
\text { stare devizne } \\
\text { štednje } \\
(\mathrm{FBiH})\end{array}$ & 511,29 & $\begin{array}{c}\text { 31.03.2011. - } \\
31.03 .2016 .\end{array}$ & $2,50 \%$ & 511,29 & 4,76 \\
\hline FBIHK3A & $\begin{array}{l}\text { Obveznice } \\
\text { Federacije } \\
\mathrm{BiH}\end{array}$ & 511,29 & $\begin{array}{c}\text { 30.05.2012. - } \\
30.05 .2015 .\end{array}$ & $5,25 \%$ & 511,29 & 2,85 \\
\hline ATFR-O-A & $\begin{array}{l}\text { Atlantik BB } \\
\text { doo Banja } \\
\text { Luka }\end{array}$ & 51,13 & $\begin{array}{c}20.06 .2011 .- \\
20.06 .2015 .\end{array}$ & $7,20 \%$ & 51,13 & 3,61 \\
\hline - & $\begin{array}{l}\text { Obveznice } \\
\text { Federacije } \\
\mathrm{BiH}^{*}\end{array}$ & 511,29 & $\begin{array}{c}26.09 .2012 . \\
26.09 .2014 .\end{array}$ & $4,30 \%$ & 511,29 & 1,96 \\
\hline FBIHK4A & $\begin{array}{l}\text { Obveznice } \\
\text { Federacije } \\
\mathrm{BiH}\end{array}$ & 511,29 & $\begin{array}{r}\text { 27.06.2012. - } \\
\text { 27.06.2017. }\end{array}$ & $6,10 \%$ & 511,29 & 4,46 \\
\hline
\end{tabular}

* Za treću seriju obveznica Federacije BiH nije određen simbol.

Izvor: www.sase.ba; www.blberza.com (Proračun autora), Microsoft Excel, 2013.

Iz prethodne tabele se jasno vidi da je od šest posmatranih obveznica na finansijskom tržištu $\mathrm{BiH}$ najmanju vrednost trajanja zabeležila obveznica FBiH treće serije čija je vrednost trajanja 1,96, godišnja kamatna stopa 4,30\% i rok dospeća od dve godine. Od svih posmatranih obveznica, data obveznica je imala najkraće dospeće što je direktno impliciralo i na najmanju vrednost trajanja. S druge strane, najveću vrednost trajanja su zabeležile municipalne obveznice opštine Bijeljina (simbol: BNIF-O-A) od 7,58. Razlog najveće vrednosti trajanja je pre svega najduži rok dospeća od svih posmatranih obveznica. Ako sada posmatramo obveznice FBiH (simbol: FBIHK4A) i obveznice stare devizne štednje (simbol: FBIHKR) ono što prvo primećujemo je to da i jedne i druge imaju isti rok dospeća od 5. godina i istu nominalnu vrednost, ali različite godišnje kamatne stope. Obveznice FBiH imaju godišnju kamatnu stopu od 6,10\%, dok obveznice stare devizne štednje imaju godišnju kamatnu stopu od 2,50. Različite godišnje kamatne stope impliciraju različita trajanja, gde obveznica s manjom godišnjom kamatnom stopom ima veću vrednost duracije, dok obveznica s većom godišnjom kamatnom stopom ima manju vrednost trajanja. Dakle, obveznice sa manjim trajanjem imaju veću nominalnu godišnju kamatnu stopu, i obrnuto, obveznice s većim trajanjem imaju manju nominalnu godišnju kamatnu stopu. Obveznice FBiH (simbol: FBIHK3A) za posmatrani period imale su trajanje od 2,85 i godišnju kamatnu stopu od 5,25\%, dok su obveznice Atlantik BB Banja Luka (simbol: ATFR-O-A) imale godišnju kamatnu stopu od 7,20\% i trajanje od 3,61\%. Sledeći grafikon ilustrije uslovljenost roka dospeća i vrednosti trajanja za određeni broj obveznica na finansijskom tržištu u BiH. 
Table 6: Value and duration for certain types of bonds on the BiH financial market

\begin{tabular}{|c|c|c|c|c|c|c|}
\hline $\begin{array}{l}\text { Bond } \\
\text { symbol }\end{array}$ & Bond type & $\begin{array}{l}\text { Nominal } \\
\text { value }\end{array}$ & $\begin{array}{c}\text { Date of issue } \\
\text { and bond } \\
\text { maturity }\end{array}$ & $\begin{array}{l}\text { Annual } \\
\text { interest } \\
\text { rate }\end{array}$ & $\begin{array}{l}\text { Bond } \\
\text { price }\end{array}$ & $\begin{array}{l}\text { Bond } \\
\text { duration }\end{array}$ \\
\hline BNIF-O-A & $\begin{array}{l}\text { Bond of the } \\
\text { old foreign } \\
\text { currency } \\
\text { savings (FBiH) }\end{array}$ & 51.13 & $\begin{array}{r}10.08 .2009- \\
10.08 .2019\end{array}$ & $6.75 \%$ & 51.13 & 7.58 \\
\hline FBIHKR & $\begin{array}{l}\text { Bond of the } \\
\text { old foreign } \\
\text { currency } \\
\text { savings (FBiH) }\end{array}$ & 511.29 & $\begin{array}{r}31.03 .2011- \\
31.03 .2016\end{array}$ & $2.50 \%$ & 511.29 & 4.76 \\
\hline FBIHK3A & $\begin{array}{l}\text { BiH Federation } \\
\text { bonds }\end{array}$ & 511.29 & $\begin{array}{r}30.05 .2012- \\
30.05 .2015\end{array}$ & $5.25 \%$ & 511.29 & 2.85 \\
\hline ATFR-O-A & $\begin{array}{l}\text { Atlantik BB dee } \\
\text { Banja Luka }\end{array}$ & 51.13 & $\begin{array}{r}20.06 .2011- \\
20.06 .2015\end{array}$ & $7.20 \%$ & 51.13 & 3.61 \\
\hline - & $\begin{array}{l}\text { BiH Federation } \\
\text { bonds* }\end{array}$ & 511.29 & $\begin{array}{r}26.09 .2012- \\
26.09 .2014\end{array}$ & $4.30 \%$ & 511.29 & 1.96 \\
\hline FBIHK4A & $\begin{array}{l}\text { BiH Federation } \\
\text { bonds }\end{array}$ & 511.29 & $\begin{array}{r}27.06 .2012- \\
27.06 .2017\end{array}$ & $6.10 \%$ & 511.29 & 4.46 \\
\hline
\end{tabular}

* For the third series of bonds of the Federation of Bosnia and Herzegovina no symbol has been specified.

Source: www.sase.ba; www.blberza.com (Calculation by author), Microsoft Excel, 2013.

It is clearly seen from the above Table that among the observed bonds traded on the financial market of $\mathrm{BiH}$, the lowest duration value was recorded by the $\mathrm{FBiH}$ bond of the third series whose duration value is 1.96 , annual interest rate $4.30 \%$, and the maturity term is two years. From all of the observed bonds, the said bond had the shortest maturity which directly implied also the lowest duration value. On the other hand, the highest duration value was recorded by the municipal bonds of the Municipality of Bijeljina (symbol: BNIF-0-A) of $7.58 \%$. The reason for the highest duration value is primarily the longest maturity term from amongst all of the observed bonds. If we are now to observe $\mathrm{FBiH}$ bonds (symbol: FBIHK4A) and the bonds of the old foreign currency savings (symbol: FBIHKR) the first thing to be noticed is that both of them have the same maturity term of 5 years, and the same nominal value, but different annual interest rates. $\mathrm{FBiH}$ bonds have the annual interest rate of $6.10 \%$, while the old foreign currency savings bonds have the annual interest rate of $2.50 \%$. Different annual interest rates imply different duration, where the bond with the lower annual interest rate has a higher duration value, while the bond with the higher annual interest rate has the lower duration value. Therefore bonds with lower duration have a higher nominal annual interest rate, and vise versa, bonds with higher duration have a lower nominal interest rate. $\mathrm{FBiH}$ bonds (symbol: FBIHK3A) for the observed period had the duration of 2.85 and the annual interest rate of $5.25 \%$, while the bonds Atlantik BB Banja Luka (symbol: ATFR0 -A) had the annual interest rate of $7.20 \%$ and the duration of $3.61 \%$. The following Graph illustrates interdependence of the maturity term and the duration value for a certain number of bonds on the financial market of Bosnia and Herzegovina. 
Grafikon 2: Međuzavisnost vrednosti trajanja i godina dospeća za određeni broj obveznica na finansijskom tržištu u $\mathrm{BiH}$

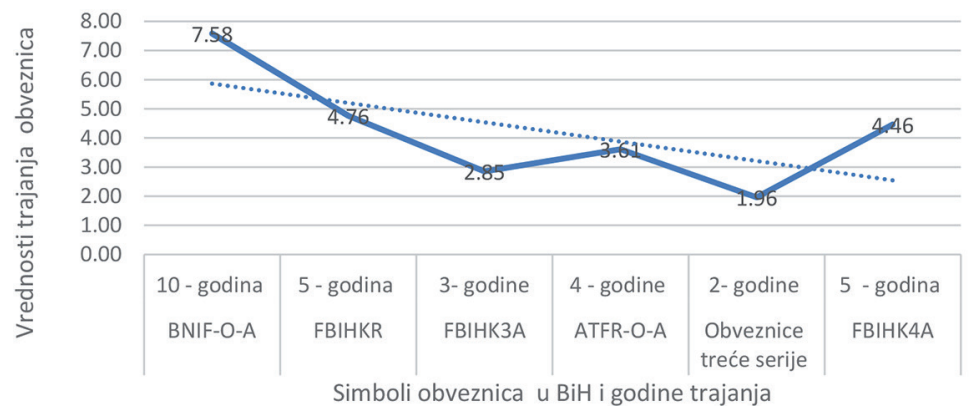

Izvor: Proračun autora, Microsoft Excel, 2013.

sa samom promenom kamatnih stopa. Mere koje se koriste za datu namenu su svakako trajanje i konveksnost. Trajanje je prosečno vreme vezivanja budućih novčanih tokova obveznice i kao takva mera je bolji pokazatelj od roka dospeća s obzirom da izražava trenutak povrata uloženih sredstava. Obveznice s visokim kuponskim stopama i visokim prinosom imaju obično niže trajanje od obveznica koje imaju manji

Grafik 2 jasno pokazuje uslovljenost između veka trajanja posmatranih obveznica i veličine trajanja gde postoji direktno proporcionalna veza u kontekstu da duži vek trajanja implicira i duže trajanje i obrnuto. Ako sada iznos kupona podelimo s godišnjom kamatnom stopom dobićemo sadašnju vrednost obveznice. Sadašnja vrednost municipalnih obveznica opštine Bijeljina iznosi 6,33\%, dok sadašnja vrednost obveznica FBiH treće serije iznosi 4,12\% cene obveznice. Ako investitor želi da ulaže u svakom slučaju poželjnije je ulagati $\mathrm{u}$ obveznice $\mathrm{s}$ kraćim rokom dospeća, iz prostog razloga bržeg povrata uloženih novčanih sredstava. Za aktivno upravljanje portfoliom obveznica potrebno je svakodnevno rebalansiranje imuniziranih portfolija. Kako se kamatne stope i duracija aktive kontinuirano menjaju, menadžeri moraju izvršiti rebalansiranje portfolija aktive s fiksnim prihodom, odnosno menjati njegovu strukturu u cilju usklađivanja trajanja portfolija obveznica s duracijom obaveza. Dakle, i ako se kamatne stope ne promene duracija aktive će se promeniti usled protoka vremena. Naime, bez rebalansiranja portfolija trajanje bi moglo da postane neusklađena mera te ciljevi imunizacije neće biti ostvareni. Stoga, je imunizacija pasivna strategija samo u smislu da ne podrazumeva pronalaženje potcenjenih hartija od vrednosti.

\section{Zaključna razmatranja}

Prilikom ulaganja $\mathrm{u}$ hartije od vrednosti s fiksnim prinosom investitori moraju imati $u$ vidu da se tržišna vrednost obveznica menja kupon ili nude niske prinose.

Trajanje kao mera ima i određene nedostatke koji se ogledaju na pretpostavci malih promena tržišne kamatne stope i linearnosti funkcije cene. Dati nedostaci se mogu otkloniti kombinacijom s merom konveksnosti, koja predstavlja krivolinijski odnos stope prinosa i tržišne vrednosti obveznice.

Generalno govoreći dva su načina na osnovu kojih se može ostvariti potencijalna dobit od aktivnog upravljanja obveznicama. Prvi način je prognoziranje kamatne stope, odnosno anticipiranje promena $\mathrm{u}$ celom segmentu tržišta hartija od vrednosti s fiksnim dohotkom. U slučaju da se predviđa pad kamatne stope menadžeri će povećati trajanje portfolija, i obrnuto ako se predviđa rast onda će skratiti trajanje portfolija. Drugi način za ostvarivanje zarada predstavlja otkrivanje potcenjenih hartija od vrednosti unutar tržišta hartija od vrednosti s fiksnim prinosom. Aktivno upravljanje obveznicama biće uspešno samo ako su analitičareve informacije ili prognoze tačnije od samog tržišta. Stoga, ne postoji mogućnost ostvarivanja dobiti ako celo tržište očekuje pad kamatnih stopa. U tom slučaju će predviđene niže buduće stope biti ugrađene $u$ cene obveznica pa će se dugoročne obveznice prodavati po višim cenama koje odražavaju anticipativni pad budućih kamatnih stopa. U ovom istraživanju smo videli da visina godišnje kamatne stope i dužina trajanja obveznica nemaju identičan uticaj na duraciju u pogledu da dužina trajanja vrši veći uticaj na samo trajanje od visine godišnje kamatne stope. 
Graph 2: Interdependence between the duration value and the maturity years for a certain number of bonds on the financial market of $\mathrm{BiH}$

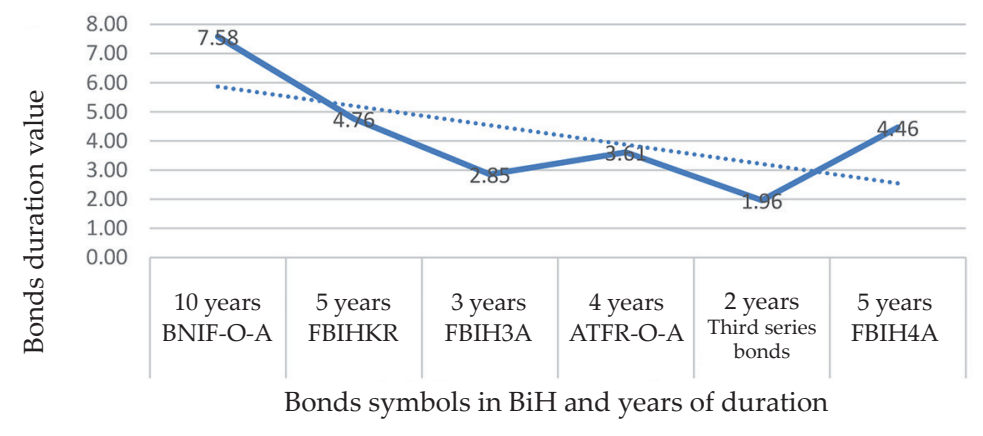

Source: Calculation by author, Microsoft Excel, 2013

value of bonds is changing with change itself in the interest rates. Measures used for the given purpose are certainly duration and convexity. Duration is the average time linking future bond cash flows and, as such a measure, it is a better indicator than the maturity term as it expresses the moment of return of the funds invested. Bonds with high coupon rates and high yield usually have lower duration than the bonds having

Graph 2 clearly indicates the interependence between the duration of the observed bonds and the size of duration where there is a directly proportional connection in the context that the longer duration time implies also the longer duration and vice versa. If we are now to divide the amount of the coupon with the annual interest rate, we will obtain the present value of the bond. Present value of the municipal bonds of the Municipality of Bijeljina amounts to $6.33 \%$, while the present value of the $\mathrm{FBiH}$ bonds of the third series is $4.12 \%$ of the bond price. If the investor wishes to invest, in any case it is more desirable to invest in bonds with the shorter maturity term, for the simple reason of a faster return of invested funds. For an active bonds portfolio management, it is necessary to rebalance on daily basis immunized portfolios. As the interest rates and duration of assets are continuously changing, managers must make rebalancing of assets portfolio with the fixed return, i.e. they must change its structure for purpose of matching bonds portfolio duration with the liabilities duration. Therefore, even if the interest rates are not to change, assets duration will change due to the elapse of time. Namely, without portfolio rebalancing duration may become a mismatched measure, and the targets of immunization will not be achieved. Hence immunization is a passive strategy only in the sense that it does not require finding of underrated securities.

\section{Final deliberations}

When investing in the fixed return securities, investors must bear in mind that the market a lower coupon or offering low yields.

Duration as a measure has also certain drawbacks which are reflected in the assumption of the small changes in the market interest rate and the linearity of the price function. The said drawbacks may be eliminated through a combination with the measure of convexity which represents a curved ratio of the bond yield rate and the market value.

Generally speaking, there are two ways on the basis of which it is possible to achieve potential gain from an active bonds management. The first way is the interest rate prognostication, i.e. anticipation of changes in the entire securities with fixed return market segment. In case a fall in the interest rate is anticipated, managers will increase their portfolio duration, and vice versa, if the growth is expected then the portfolio duration will be shortened. The other way to achieve gain is discovery of potential underrated securities within the fixed yield securities market. Active bonds management will be successful only if the analyst's information or prognosis is more correct than the market itself. Hence there is no option of making gain if the entire market is anticipating the fall in the interest rates. In that case, the anticipated future lower rates will be built in the bond price and the longterm bonds will sell at higher prices which reflect the anticipated fall in the future interest rates. In this research we have seen that the level of the annual interest rate and the bonds duration length do not have an identical impact on duration in view of the fact that the length of duration is making a bigger impact on duration itself than the level of the annual interest rate. 


\section{Literatura / References}

1. Alihodžić, A. (2010). Modeli vrednovanja obveznica, Časopis za teoriju i praksu : Ekonomija, Informacione tehnologije, menadžment - Singidunum Revija, Beograd, Vol. 7 No. 2, str. 329 - 340. Dostupno na: http://www.google.ba/url?sa=t\&rct=j\&q=\& esrc $=$ s\&source $=$ web\&cd $=8 \&$ ved $=0$ CGQQFj AH\&url=http $\% 3 \mathrm{~A} \% 2 \mathrm{~F} \% 2 \mathrm{Fw} w w$. singipedia. com\%2Fattachment.php\%3Fattachmentid\% 3D1654\%26d\%3D1288373659\&ei=hhYwUsn dHcrQsgbKvIHwBQ\&usg=AFQjCNHBM4 bol-U9VNJzECsckzSx2KdzNg\&sig2=7biR_ DXN3c-iQXtSs8XXEg

2. Aljinović, Z., Marasović, B., Šego, B. (2011). "Financijsko modeliranje“, Sveučilište u Splitu - Ekonomski fakultet Split.
3. Bierwag, G.O. (1987). "Duration Analysis“. Cambridge: Ballinger Publication

4. Bodie, Z., Kane, A., Marcus, J. A. (2009). "Osnovi investicija", DATA STATUS, Beograd

5. Bodie, Z., Kane, A., Marcus, A. (2006). „Počela ulaganja“, MATE doo Zagreb.

6. Choudhry, M. (2010). "An Introduction to bond markets", John Wiley and Sons.

7. Erić, D., Đukić, M. (2012). „Finansijska tržišta u uslovima krize“, Institut ekonomskih nauka, Beogradska bankarska akademija - Fakultet za bankarstvo, osiguranje i finansije, Beograd.

8. Kurbegović, T., Mirica, A., Martinčević, A. (2012). „Povezivanje tržišta kapitala u uslovima globalizacije - sedma Međunarodna konferencija", Sarajevska berza, Sarajevo. 
9. Steiner, R. (1999). „Mastering Financial Calculations," Pearson Education, Harlow.

10. Šoškić, D., Živković, B. (2009). „Finansijska tržišta i institucije“, Centar za izdavačku delatnost Ekonomskog fakulteta u Beogradu.

11. Vukičević, M., Gregurek, M., Odobašić, S., Grgić, J. (2010.). „Finansijski menadžment u MS Excelu“, Golden marketing - Tehnička knjiga, Zagreb.

12. Web stranica Registra vrednosnih papira u FBiH: http://www.rvp.ba

13. Web stranica Komisije za vrednosne papire u FBiH: http://www.komvp.gov.ba

14. Web stranica Sarajevske berze vrednosnih papira: http://www.sase.ba
15. Web stranica Banjalučke berze hartija od vrednosti: http://www.blberza.com

16. Web stranica Komisije za hartije od vrednosti Republike Srpske: http://www.secrs.gov.ba

17. Web stranica Centralnog Registra hartija od vrijednosti Republike Srpske: http://www. crhovrs.org

18. https://raiffeisenbank.ba/templates/ default/invest/20130812164206_ Raiffeisensedmicniizvjestaj05.08.09.08.2013. pdf

19. http://www.investopedia.com/university/ advancedbond/advancedbond5.asp 